\title{
Making Sense: hands, faces \& creation in Rilke's Auguste Rodin and Die Aufzeichnungen des Malte Laurids Brigge
}

\begin{abstract}
Readers of Rilke's writings on Rodin may well be surprised to find them just as full of isolated body parts as is his notoriously fragmentary novel, Die Aufzeichnungen des Malte Laurids Brigge. Here they are not gruesome, but part of an aesthetic mereology (system of parts and wholes) that governs, at least according to Rilke, the metaphysics of the artwork. Not only are these body parts separable from the whole work, or person, but the sensory interactions between them seem also to obey their own laws: in Rodin, they help bring about and maintain what is called the 'Kunst-Ding' as a differentiated object belonging in but not to, the world of everyday things; in Malte, in the faces that don't fit and hands that don't follow orders, grotesque sensory misidentifications stymie the desire to be 'wirklich', and recognition is a verbal, not visual, matter. The two texts are drawn together in their shared project of positing a theory of aesthetic creation in which the senses are used by both creator and viewer to bring about the artwork as a wholly unique and self-governed entity — and the problems of this project are exposed.
\end{abstract}

Keywords: Rainer Maria Rilke, Die Aufzeichnungen des Malte Laurids Brigge, Auguste Rodin, ekphrasis, the senses, criticism

Author Bio/funding: Rey Conquer is Stipendiary Lecturer at St Hilda's College, Oxford. The research undertaken for this article was funded by the first part of an Arts and Humanities Research Council ' $1+3$ ' grant (may they be reinstated).

To a reader of Rilke's writings on Rodin, or of his novel, Die Aufzeichnungen des Malte Laurids Brigge, it might seem that the texts are littered with hands and faces unattached to any body or person, at times gruesome, at times sublime. These hands and faces are equally unattached to the senses of sight and touch, which operate in radically intertwined ways. Both works share a fixation with the look: in one, as part of lyrical ekphrasis as well as a sketch of a potential paradigm of aesthetic reception, in the other, as part of Malte's more personal project of 'learning to see'. This is where the similarities between the works would seem to peter out; where one is optimistic in its view of art and draws out the creative potential in the fragmentation of the body and the senses, the other describes the creative sterility of modernity. The present study explores the relationship between these fragmented body parts and the complex use of the 
senses of sight and touch in the two works, asking how it can be that similar images and conceptions of sensory experience can play out in such fundamentally different ways. ${ }^{1}$

The associative link between the face and sight is flagged up in German through the double meaning of 'Gesicht', and Georg Simmel, whose lectures Rilke attended, draws out this association in a discussion of the inherent reciprocity of vision, where the eye stands for vision tout court and the face for the visual encounter between subjects:

Die besondre, soziologisch folgenreiche Art des 'Kennens', die das Auge vermittelt, wird dadurch bestimmt, dass das Antlitz das wesentliche Objekt des interindividuellen Sehens ist. ${ }^{2}$

This conception makes explicit the two-directional nature of sight, which Simmel sees as central to any sociological exploration of the senses, in opposition to those philosophers of the senses for whom seeing is, particularly in contradistinction to touch, uni-directional. ${ }^{3}$ It is the possibility of reciprocity that seems in question in both Auguste Rodin and Malte (as well as in Rilke's poetry of this period, with 'Orpheus. Eurydike. Hermes' as a paradigm). In both, the un-met gaze - that is, a gaze that ought structurally to allow for reciprocity but 'misfires' - seems at first sight to involve a regrettable objectification and consequent distance from the things - person, artwork seen; in reciprocity, balance and a critical propriety can be achieved.

\section{The creative gaze in Auguste Rodin}

Dem Künstler steht es zu, aus vielen Dingen eines zu machen und aus dem kleinsten Teil eines Dinges eine Welt. $(421)^{4}$

\footnotetext{
${ }^{1}$ Previous discussions of hands in Malte include Idris Parry, 'Malte's Hand' German Life and Letters 11 (1957) 112, and Frederic C. Tubach, 'The Image of the Hand in Rilke's Poetry' PMLA 76 (1961) 240-6.

${ }^{2}$ Rilke was a student under Simmel for a while, and may well have read this essay when it was published in Die Neue Rundschau. Page numbers here refer to 'Soziologie der Sinne' in Gesamtausgabe in 24 Bänden: Bd. 8 Aufsätze und Abhandlungen 1901-1908 Band II Ed. Alessandro Cavalli und Volkhard Krech (Frankfurt am Main: Suhrkamp, 1993) pp. 276-292. Hans-Jürgen Schings has described Malte as a 'Simmel-Kritiker' in his essay on the ways that Rilke appears to be responding to Simmel's sociology in Malte, 'Die Fragen des Malte Laurids Brigge und Georg Simmel', DVjs, 76 (2002), 643-71 (671). Neil H. Donahue argues that Malte shows Rilke moving from a reliance on Simmel and sociology to an exploration of Worringer's aesthetics. Regardless of the plausibility of this claim, his discussions of their overlaps are helpful. Neil H. Donahue, 'Fear and Fascination in the Big City: Rilke's Use of George Simmel' in The Notebooks of Malte Laurids Brigge' Studies in Twentieth-century Literature 16 (1992) 197-219.

${ }^{3}$ One might think here of the later Hans Jonas, for whom sight is distinguished by 'the complete absence of [...] a dynamical situation, of any intrusion of causality into the relation [...]. I have to do nothing but to look, and the object is not affected by that: and once there is light, the object has only to be there to be visible, and I am not affected by that'. Hans Jonas, 'The Nobility of Sight' Philosophy and Phenomenological Research 14 (1954) 507519 (515).

${ }^{4}$ I concentrate on the essay, written in late 1902 and first published as Auguste Rodin in March 1903, and on the lecture, delivered in 1905 and added to the 'Dritte, erweiterte Auflage' of 1907. Both are cited from Rilke, Rainer Maria. Kommentierte Ausgabe, 4 vols, ed. Manfred Engel et al. (Frankfurt am Main: Insel, 1996) vol. 4 pp. 401-483. I will occasionally refer to letters and drafts written in the most part between 1902 and 1907, KA vol. 4 pp. 485-513
} 
In his writings on Rodin, Rilke takes as central to the sculptor's work his ability to achieve a wholeness in his finished pieces, even those which seem at first glance 'incomplete'. A face, a headless, armless man, a hand: fragments of bodies populated his work and studio, and this stripping down of the human body to the bare expressive essentials held great appeal for Rilke. ${ }^{5}$ A complex mereology of the artwork emerges in which 'whole' and 'part' cannot be determined in relationship to each other without calling upon the relationship between the artwork and its object or model, and of the artwork to a deeper reality or essence. ${ }^{6}$ This deeper reality is, according to Rilke, 'Leben': a force which both creates the work, through the sculptor's hands, and is expressed by the work. This 'life' flows unimpeded from what is represented, via the hands of the sculptor, through the sculpture to the viewer. The fragmented body is therefore seen as central to Rodin's work and a necessary artistic move, as this vitalistic expression of 'Leben', or the essence of the original, takes priority over crudely illusionistic depiction. A sculpture need not, for instance, have arms to be 'complete', and in many cases is a more truthful work of art without them (the example Rilke gives is La Méditation, known also as La voix antérieur). ${ }^{7}$ More important are the structures of movement and surface, and their interaction with the viewer, in creating an artwork that is 'whole'. In the words of Heinrich Wölfflin, who, although describing Baroque art, could well have been referring to Rodin: 'Das Ganze gewinnt den Schein einer rastlos quellenden, nie endenden Bewegung. ${ }^{8}$

Rilke sees in Rodin's work a necessary ontological discrepancy between 'Ding', i.e. the mundane object, including the model or original of a sculpture, and 'Kunst-Ding'; the art-object is removed from the normal spatio-temporal bounds, away from time and contigency and into a

and Gesammelte Briefe ed Ruth Sieber-Rilke and Carl Sieber (Leipzig: Insel, 1939) vol. 1. Citations by page number alone in this section refer to $K A$ vol. 4 .

${ }^{5}$ In a letter to Clara Westhoff of the second of September 1902, Rilke describes the 'Riesenvitrinen' that are filled with fragments from the Porte de l'Enfer: 'Da liegt es meterweit nur Bruchstücke, eines neben dem anderen.' Briefe $\mathrm{I}: 252$.

${ }^{6}$ The concept of 'mereology' I borrow from the philosophical area of ontology, where it means 'the logic of the relationship of part to whole' (Simon Blackburn, Oxford Dictionary of Philosophy (Oxford: Oxford University Press, 1994) p. 239) or 'formal theory of part, whole, and related concepts' (Peter Simons, Parts: A Study in Ontology (Oxford: Clarendon Press, 1987) p. 1).

${ }^{7}$ Frances Mary Scholz suggests this is also a function of Rodin's being something of a womaniser, or, in her words, 'Latin sensualist', which is rather uncritically phrased but which hits on something well worth examining, namely, the question of gender in relation to parts and wholes as it plays out in Rodin, especially alongside similar theories put forward by, for example, Simmel in Philosophische Kultur. 'Rilke, Rodin, and the fragmented man' Symposium 30 (1976) 61-74 (70-1).

${ }^{8}$ Heinrich Wölfflin, Kunstgeschichtliche Grundbegriffe - Das Problem der Stilentwicklung in der neueren Kunst (Munich: Bruckmann, 1915) p. 21. Wölfflin arrived to teach at Berlin in 1901, by which point Rilke was no longer attending lectures there, but is likely to have come across his work. 
realm of necessity. Rilke summarises this in a well-known letter to Lou Salomé of the $8^{\text {th }}$ August 1903:

Das Ding ist bestimmt, das Kunst-Ding muß noch bestimmter sein; von allem Zufall fortgenommen, jeder Klarheit entrückt, der Zeit enthoben und dem Raum gegeben, ist es dauernd geworden, fähig zur Ewigkeit. Das Modell scheint, das Kunst-Ding ist. (Briefe I:377)

Art-objects which exemplify this for Rilke include statues from antiquity and the animals which decorate medieval cathedrals. Writing at more length of such figures in his monograph on Rodin, Rilke claims, 'Die Not hatte sie geschaffen' (408). This is at once a psychological need and a metaphysical necessity; the sculptures are created by humans who need to express their faith in God by instantiating it in physical objects, but who, in so doing, are responding to a deeper sense that these are things which must, given the way the world is, exist. And it is sculpture, not painting ('eine Täuschung, ein schöner und geschickter Betrug' (408)), which satisfies this need, at once more real and more simple (408). For Rilke, Rodin is a modern-day "'tailleur d'ymaiges"' - 'dieser Titel, den die Meister des Mittelalters einander in neidloser ernster Wertung gaben' - (418) whose art similarly responds not to 'Laune' but to 'Not'. The priority given to sculpture is explained by the structures by which it is determined: 'Fläche' (the 'Grundelement seiner Kunst' (411)) and 'Bewegung'. These can be considered the space and time of the art-object world: movement is only perceivable over time, and is therefore so interpreted in the everyday world, but it is clear that this movement is not constrained by time, instead being 'fähig zur Ewigkeit'.

The interaction between the artwork and the surrounding space reinforces the ontological separateness of the art-object. Towards the end of the first essay, Rilke likens Rodin's 'Dinge' once again to medieval cathedral animals; what they have in common is the way they are changed by the 'Luft' or 'Raum' which surrounds them, which is nonetheless subservient to the sculpture:

Für Rodin war immer schon die Teilnahme der Luft von großer Bedeutung. [...]Hatten seine Dinge früher im Raume gestanden, so war es jetzt, als risse er sie zu sich her. Nur bei einzelnen Tieren auf den Kathedralen konnte man Ähnliches beobachten. Auch an ihnen nahm die Luft in eigentumlicher Weise teil: es schien, als würde sie Stille oder Wind, je nachdem sie über betonte oder über leise Stellen ging. [...] Auch sie hatte zusammengefaßt, vertieft und Staub abgesetzt, hatte mit Regen und Frost, mit Sonne und Sturm diese Dinge erzogen für ein Leben, das langsamer verging in Ragen, Dunkeln und Dauern.

Schon bei den Bürgern von Calais war Rodin auf seinem eigenen Wege zu dieser Wirkung gekommen; in ihr lag das monumentale Prinzip seiner Kunst. Mit solchen Mitteln konnte er weithin sichtbare Dinge schaffen, Dinge, die nicht nur von der allernächsten Luft umgeben waren, sondern von dem ganzen Himmel. Er konnte mit einer lebendigen Fläche, wie mit einem Spiegel, die Fernen fangen und bewegen, und er konnte eine Gebärde, die ihm groß schien, formen und den Raum zwingen, daran teilzunehmen. (434-4) 
Thus, the world of the 'Kunst-Ding' and the world of the 'Ding' are interdependent, although the structures of the former determine the mode of interaction. Here Rilke uses the example of how weather can both change the way a sculpture appears to a viewer, and change the sculpture over time. This concrete interaction is elided with a more transcendental conception of air and space determined by a relation of necessity, most explicitly described in the following passage on the 'Kunst-Ding':

Es mußte seinen eigenen, sicheren Platz erhalten, an den nicht Willkür es gestellt hatte, und es mußte eingeschaltet werden in die stille Dauer des Raumes und in seine großen Gesetze. In die Luft, die es umgab, mußte man es wie in eine Nische hineinpassen und ihm so eine Sicherheit geben, einen Halt und eine Hoheit, die aus seinem einfachen Dasein, nicht aus seiner Bedeutung kam. (410)

The art-object has a pre-determined place in 'die stille Dauer des Raumes' and is bound by its 'großen Gesetze'; its sublimity is dependent on this placing, not as a matter of interpretation but simply through its being.

It is here, when considering the mutually dependent relationship between art-object and space, that it becomes clear that for a viewer to do any justice to the sculpture, the senses cannot operate singly. The sculpture is not a picture that one can simply look at; to fully appreciate it, one must be able to walk around it: 'Es war ein Ding, das für sich allein bestehen konnte, und es war gut, ihm ganz das Wesen eines Dinges zu geben, um das man herumgehen und das man von allen Seiten betrachten konnte' (410). The sculpture must take on certain properties of the 'Ding', namely, three-dimensionality, in order to be apprehensible to the viewer, just as it harnesses the space around it in self-creation and maintenance. We are reminded, however, that the 'KunstDing' is of necessity a different sort of thing, and that although we approach it, we can never truly have access to it through the senses:

Und doch mußte es sich irgendwie von den anderen Dingen unterscheiden, den gewöhnlichen Dingen, denen jeder ins Gesicht greifen konnte. Es mußte irgendwie unantastbar werden, sakrosankt, getrennt vom Zufall und von der Zeit, in der es einsam und wunderbar wie das Gesicht eines Hellsehers aufstand. (410)

Thus the existence in space of the art-object must have to do with, but transcend, properties and structures of the world of objects in order to have an effect on the viewer, just as the sculpture must express the 'Wesen' of its object but transform and transcend the boundaries of likeness (as with the sculpture of Balzac: 'Er hat ihn im Grunde seines Wesens erfaßt' (445)). This must, Rilke claims, necessarily be so: the artwork must be 'getrennt vom Zufall'.

It is this necessity that dictates the mereology of the artwork. Parts relate to wholes not in relation to how objects in the everyday world are divided up, but 'aus innerer Notwendigkeit':

Rodin aber, der durch die Erziehung, die er sich gegeben hat, weiß, daß der Körper aus lauter Schauplätzen des Lebens besteht, eines Lebens, das auf jeder Stelle individuell und groß werden kann, hat die Macht, irgendeinem Teil dieser weiten schwingenden Fläche die Selbständigkeit und 
Fülle eines Ganzen zu geben. Wie der menschliche Körper für Rodin nur so lange ein Ganzes ist, als eine gemeinsame (innere oder äußere) Aktion alle seine Glieder und Kräfte im Aufgebot hält, so ordnen sich ihm andererseits auch Teile verschiedener Leiber, die aus innerer Notwendigkeit aneinander haften, zu einem Organismus ein. (422)

The artwork could consist of a hand or a face, an armless body or an entire group and only be considered whole if it expressed the essence or 'Leben' of the represented thing, person or scene. Even the words used above - hand, face, arm - to divide up the perceived 'parts', belong to the world of things; in the world of the object, they may (almost literally) 'carve Nature at the joints', but when used to describe the artwork they are a mere imposition of language by the viewer on the 'namenloses Leben' $(416,433)$ of the Kunst-Ding. For Rilke, such distinctions do not suggest 'natural kinds' in the metaphysics of the art-thing, and in naming and thereby distinguishing, artists would be displaying a kind of disobedience to what they were creating:

Diese Arbeit (die Arbeit am Modelé) war die gleiche bei allem, was man machte, und sie mußte so demütig, so dienend, so hingegeben getan sein, so ohne Wahl an Gesicht und Hand und Leib, daß nichts Benanntes mehr da war, daß man nur formte, ohne zu wissen, was gerade entstand, wie der Wurm, der seinen Gang macht im Dunkel von Stelle zu Stelle. Denn wer ist noch unbefangen Formen gegenüber, die einen Namen haben? Wer wählt nicht schon aus, wenn er etwas Gesicht nennt? Der Schaffende aber hat nicht das Recht zu wählen. Seine Arbeit muß von gleichmäßigem Gehorsam durchdrungen sein. Uneröffnet gleichsam, wie Anvertrautes, müssen die Formen durch seine Finger gehen, um rein und heil in seinem Werke zu sein. (461)

This passage draws our attention to an important distinction between the 'Kunst-Ding' and the 'Ding': the former does not respond to reason, and any appreciation of the artwork must be undertaken through intuition rather than thought. This plays, for Rilke, a central role in our understanding of a work's wholeness, and to see a Rodin sculpture as unfinished would not stem from ‘einfache[s] Schauen' but 'umständliche[ ] Überlegung', and would demonstrate a 'kleinliche Pedanterie, welche sagt, daß zu einem Körper Arme gehören und daß ein Körper ohne Arme nicht ganz sein könne, auf keinen Fall' (421). Viewers are allowed a richer experience of an artwork when they reject an intellectual approach; a factual knowledge of the material ('Stoff') from which Rodin has drawn inspiration can inform one's encounter, but does not improve it:

Man kann, wenn man will, die meisten Werke Rodins mit Gedanken begleiten, erklären und umgeben. Für alle, denen das einfache Schauen ein zu ungewohnter und schwerer Weg zur Schönheit ist, gibt es andere Wege, Umwege über Bedeutungen, die edel sind, groß und voll Gestalt. [...] Nie ist ein Stoff bei Rodin an ein Kunstding gebunden, wie ein Tier an einen Baum. Er lebt irgendwo in der Nähe des Dinges und lebt von ihm, etwa wie der Kustos einer Sammlung. Man erfährt manches, wenn man ihn ruft; wenn man es aber versteht, ohne ihn auszukommen, ist man mehr allein und ungestört und erfährt noch mehr. (430)

This rejection is not an easy step to take, yet the rewards are, according to Rilke, great. The passage continues: 
Wo die erste Anregung vom Stofflichen ausging, wo eine antike Sage, die Stelle eines Gedichtes, eine historische Szene oder eine wirkliche Person Schaffensanlaß war, da übersetzt sich, wenn Rodin beginnt, während der Arbeit das Stoffliche immer mehr in Sachliches und Namenloses: in die Sprache der Hände übertragen, haben die Anforderungen, die sich ergeben, alle einen neuen, ganz auf die plastische Erfüllung bezüglichen Sinn. (430)

The process of creation becomes a stripping away of any intellectual meaning, transforming the material, which is knowable through reason, into art, which is best accessed through the senses without any attempt at interpretation.

What this passage also makes clear is that the primary organ of creation is the hand, and the hand is endowed with transformative and interpretative agency. This is to some degree a form of lyrical metonymy, where by hands Rilke is referring to the man or his creative prowess, as in this passage from the very beginning of the essay:

$[\mathrm{M}]$ an sieht sich unwillkürlich nach den zwei Händen um, aus denen diese Welt erwachsen ist. Man erinnert sich, wie klein Menschenhände sind, wie bald sie müde werden und wie wenig Zeit ihnen gegeben ist, sich zu regen. Und man verlangt die Hände zu sehen, die gelebt haben wie hundert Hände, wie ein Volk von Händen, das vor Sonnenaufgang sich erhob zum weiten Wege dieses Werkes. Man fragt nach dem, der diese Hände beherrscht. Wer ist dieser Mann? (405)

Even here, however, Rilke is committed to the creative autonomy of the hands, and the use of 'beherrscht' seems almost an oversight, for elsewhere it is clear that in his account of artistic creation, the hands are on an equal footing with the 'man' to whom they are attached. These hands may be those of the creator, or those of the artwork, where they are 'lebendig', 'Hände, die sich aufrichten, gereizt und böse',

Aber Hände sind schon ein komplizierter Organismus, ein Delta, in dem viel fernherkommendes Leben zusammenfließt, um sich in den großen Strom der Tat zu ergießen. Es gibt eine Geschichte der Hände, sie haben tatsächlich ihre eigene Kultur, ihre besondere Schönheit; man gesteht ihnen das Recht zu, eine eigene Entwickelung zu haben, eigene Wünsche, Gefühle, Launen und Liebhabereien. (422)

Rilke's argument can be brought into sharper focus by comparing and contrasting it with Heidegger's later reflections on the hand and handiwork. The similarities between the two passages suggest Heidegger was thinking of the above passage from Rodin when writing in Was heißt Denken?:

Mit der Hand hat [das Denken] eine eigene Bewandtnis. Die Hand gehört nach der gewöhnlichen Vorstellung zum Organismus unseres Leibes. Allein das Wesen der Hand läßt sich nie als ein leibliches Greiforgan bestimmen oder von diesem her erklären. Greiforgane besitzt z.B. der Affe, aber er hat keine Hand. Die Hand ist von allen Greiforganen: Tatzen, Krallen, Fängen, unendlich, d.h. durch einen Abgrund des Wesens verschieden. Nur ein Wesen, das spricht, d.h. denkt, kann die Hand haben und in der Handhabung Werke der Hand vollbringen.

Allein das Werk der Hand ist reicher, als wir gewöhnlich meinen. Die Hand greift und fängt nicht nur, drückt und stößt nicht nur. [...] Die Hand hält. Die Hand trägt. Die Hand zeichnet, vermutlich weil der Mensch ein Zeichen ist. Die Hände falten sich, wenn diese Gebärde den Menschen in die 
größte Einfalt tragen soll. [...] Darum ist das Denken selbst das einfachste und deshalb schwerste Hand-Werk des Menschen, wenn es zu Zeiten eigens vollbracht sein möchte. ${ }^{9}$

For Heidegger, the hand cannot be reduced to its physiological functions of holding and gripping, but is, in the words of the architectural theorist Juhani Pallasmaa, an 'organ of thought', whose work is rooted in thinking, and in whose work thinking is rooted. ${ }^{10}$ He rests this on the communicative work that hands - as opposed to claws, paws, etc. - are involved in, unique to humans, for the reason that humans speak, and therefore, according to Heidegger, think. For Rilke, the hand is only an organ of thought insofar as it is self-determining and makes without explicit direction, thus thinking, in some sense, for itself. Direct sensing is privileged over interpreting or intellectualising in the creation as well as the reception of the artwork. In many cases, it would seem that there is a shortcut through the hands between model or material and the artwork, bypassing the intellect. The hands have access to dreams (409) and memory, and, as in the following passage, have an active role in the transformation of 'Stoff' into 'Kunst':

Sein Auge sieht während der Sitzungsstunden viel mehr, als er in dieser Zeit ausführen kann. Er vergißt nichts davon, und oft, wenn das Modell ihn verlassen hat, beginnt für ihn das eigentliche Arbeiten aus der Fülle seiner Erinnerung. Seine Erinnerung ist weit und geräumig; die Eindrücke verändern sich nicht in ihr, aber sie gewöhnen sich an ihre Wohnung, und wenn sie von da in seine Hände steigen, so ist es, als wären sie natürliche Gebärden dieser Hände. (437)

We are reminded that the primary mode of expression between the artwork and the viewer is the gesture, 'Gebärde', which can be both literally understood, as in Les Bourgeois de Calais (444, see p.xx), but also as a poetic reduction of the artwork as a whole ('phantastisch ragenden Felsen am Meer, in dessen seltsamen Formen entfernte Völker eine Gebärde schlafen sahen’ (439)) and as synonymous with movement: 'Da waren Steine, [...] die eine Bewegung trugen, eine Gebärde, die so frisch geblieben war, als sollte sie hier nur aufbewahrt und eines Tages irgend einem Kind gegeben werden, das vorüberkam' (406).

Gesture is then clearly not limited to hands, but they are its chief vehicle. As such, they play an important part in the self-definition of the artwork, the maintenance of the boundaries between Kunst-Ding and Ding. 'Gebärde' is the main interpretative tool for the viewer to make use of when understanding the artwork, as it is the most eloquent. In conveying this gesture, hands reach out to the viewer, but remind us of the material existence and boundedness of the artwork in their own physical boundedness; in affecting to cross from the realm of the art-object they serve to make us aware of its existence, of the sublime 'Unantastbarkeit' of the Kunst-Ding. ${ }^{11}$

\footnotetext{
${ }^{9}$ Was heißt Denken? Ed. Paola-Ludovika Coriando (Frankfurt am Main: Vittorio Klostermann, 2002) pp. 18-19.

${ }^{10}$ Juhani Pallasmaa, The Eyes of the Skin (London: Academy Editions, 1996), p. 60. Pallasmaa also makes this connection between the passages from Rilke and Heidegger, but does not explicate them.

${ }^{11}$ Brigid Doherty makes the intriguing comparison between the lecturing styles of Rilke and Simmel as against Wölfflin; where the art historian attempts to make himself invisible next to the reproduced work of art, Rilke invokes, perhaps in delivering his Rodin lecture even made, the gesture of a fist, akin, she suggests, to the
} 
Touch within the artwork has a similar function, in that it builds boundaries by connecting, unifying the artwork by separating it out from the world around it: 'Er schuf Körper, die sich überall berührten und zusammenhielten wie ineinander verbissene Tiere, die als ein Ding in die Tiefe fallen' (427). Even in cases where the viewer would have, for the sake of content, reason to separate out figures within a work, the use of touch between figures counteracts this tendency of interpretation. Writing of Rodin's sculpture of Victor Hugo, Rilke describes how the muses surrounding the poet become one with him through points of contact, 'Berührungsstellen':

Durch die Verinnerlichung der einzelnen Figuren und die Konzentration, man möchte sagen: um das Innere des Dichters, hat Rodin diesen Eindruck erreicht; indem er auch hier wieder von einer Individualisierung der Berührungsstellen ausging, ist es ihm gelungen, die wundervoll bewegten Akte gleichsam zu Organen des sitzenden Mannes zu machen. Sie sind um ihn wie große Gebärden, die er einmal getan hat, Gebärden, die so schön und jung waren, daß ihnen eine Göttin die Gnade verlieh, nicht zu vergehen und in der Gestalt schöner Frauen immer zu dauern. (439)

This physical contact between the bodies makes of them one organism, and of the women merely gestures that the poet had once made, emanations of his 'Wesen' but inseparable from him.

According to Rilke, gesture which escapes the bounds of the sculpture only to fall back in again, like a fountain, is characteristic of the art of antiquity, of which he sees Rodin as a modern-day continuation:

Es waren Strömungen in den verschlossenen Göttern, welche saßen, und in den stehenden war eine Gebärde, die wie eine Fontäne aus dem Steine stieg und wieder in denselben zurückfiel, ihn mit vielen Wellen erfüllend. Nicht die Bewegung war es, die dem Sinne der Skulptur (und das heißt einfach dem Wesen des Dinges) widerstrebte; es war nur die Bewegung, die nicht zu Ende geht, die nicht von anderen im Gleichgewicht gehalten wird, die hinausweist über die Grenzen des Dinges. [...] Was die Dinge auszeichnet, dieses Ganz-mit-sich-Beschäftigtsein, das war es, was einer Plastik ihre Ruhe gab; sie durfte nichts von außen verlangen oder erwarten, sich auf nichts beziehen, was draußen lag, nichts sehen, was nicht in ihr war. Ihre Umgebung mußte in ihr liegen. (417-8)

We can compare this to the poem in the Neue Gedichte, 'Römische Fontäne', with its equilibrium of 'neigend' and 'wartend' and the suggestion in the final, feminine 'Übergängen' of something outside of the fountain, yet otherwise entirely enclosed within itself, secretive. Both the fountain and the sculptures of Rodin are engaged in what Rilke calls 'dieses Sich-nach-innenBiegen', 'dieses angestrengte Horchen in die eigene Tiefe' (420). Not only touch, but also hearing is directed back inwards, hearing which need not be directed towards sound - Rodin creates 'Leiber, die horchten wie Gesichter' (427) - but is instead indicative of an openness to receiving oneself, predicated on the radical separateness of the sculpture from the viewing subject who would not be able to hear the unspoken messages the Kunst-Ding might relay.

\footnotetext{
'unforgettable gestures' Ludwig Marcuse recalled of Simmel's lectures. Brigid Doherty, 'Rilke's Magic Lantern: Figural Language and the Projection of "Interior Action" in the Rodin Lecture' in Ewa Lajer-Burcharth and Beate Söntgen, eds., Interiors and Interiority (Berlin: De Gruyter, 2016), pp. 313-346 (p. 335 n. 46).
} 
The most important source of the impermeability of sculpture to the outside world is 'Gesichter', and in a passage from his unpublished notes on Rodin Rilke sets out one of his most remarkable observations:

Für Plastik ist noch ein Umstand ungemein wichtig: dass das Kunstwerk in sich zu Ende geht. Ein 'Aus-dem-Bild-Herausschauen' ist insofern nie der Fall, als das Bild nimmer vor der betreffenden gemeinten Figur noch zu erweitern ist (Vordergrund) in demselben Maße wie hinter derselben, so daß der Blick der Gestalt immer noch im Bilde bleibt und vom Beschauer wie durch einen nicht leitenden luftleeren Raum getrennt ist. Die Plastik, die mit dem Beschauer dieselbe Atmosphäre teilt, muß das 'Wegschauen' besser können. Das heißt: Sie muß mit sich ganz beschäftigt sein. Auch dies hat Rodin vollkommen erreicht, bei Gruppen sind die Blicke immer in Beziehung miteinander, es gibt weder bei Einzelnen noch bei Gestaltbildern Augen, die nicht innerhalb des Werkes wirksam, d.h. gebunden wären. Kein Beschauer (und nicht der eingebildeteste) wird behaupten können, dass ihn eine Porträtbüste Rodin's, etwa Rochefort oder Falguière oder gar der begeisterte Balzac angesehen hätten! (488-9)

The gaze is used by Rodin to 'seal off' the artwork from the outside world, in a way that does not depend on material form but instead with a frustrated interaction between viewer and sculpture. Where gesture and touch originate with the concrete form of the hand, the gaze is pure direction, and can only be perceived as such by one's own gaze as a beholding subject not being met (as Rilke says, even the most conceited of viewers would not dare claim that Rodin's Balzac had looked them in the eye). Thus the separateness of the artwork is maintained by a kind of forcefield which arises through a dialectic in which reciprocity is achieved only within the work and never across the gulf between work and world.

A somewhat more polemical version of the same is offered in Rilke's famous poem, 'Archaischer Torso Apollos', often read alongside Rodin if only for the superficial reason of shared content. Here the forcefield is created through the transformation of what are in Rodin 'lebendige Stellen' to 'sehende Stellen'. The statue does not belong to the same world as the viewer; set apart linguistically by the use of the subjunctive, the realm of the Kunst-Ding is invoked. Here, the laws of 'Fläche' and 'Bewegung' allow the statue an ethical primacy, allow its every 'Stelle', disobeying the physical laws of the everyday world, become, in Paul de Man's phrase, 'an Argus eye capable of engendering, by itself, all the dimensions of space', to see the viewer and utter the final injunction. ${ }^{12}$ The creation of art-space through the gaze is central to the work of Rodin as Rilke sees it, and it is this picture of the art-object that Die Aufzeichnungen des Malte Laurids Brigge questions.

\footnotetext{
12 Paul De Man, Allegories of Reading (New Haven and London: Yale University Press, 1979) p. 56.
} 


\section{Disintegration in Die Aufzeichnungen des Malte Laurids Brigge}

Die Straße war zu leer, ihre Leere langweilte sich und zog mir den Schritt unter den Füßen weg und klappte mit ihm herum, drüben und da, wie mit einem Holzschuh. Die Frau erschrak und hob sich aus sich ab, zu schnell, zu heftig, so daß das Gesicht in den zwei Händen blieb. Ich konnte es darin liegen sehen, seine hohle Form. Es kostete mich unbeschreibliche Anstrengung, bei diesen Händen zu bleiben und nicht zu schauen, was sich aus ihnen abgerissen hatte. Mir graute, ein Gesicht von innen zu sehen, aber ich fürchtete mich doch noch viel mehr vor dem bloßen wunden Kopf ohne Gesicht. ${ }^{13}$

Where the frustrated gaze in Rodin allows for the creation of artistic space, in Malte it directs us to the central ethical and aesthetic question at the heart of the novel: how to live, and create, authentically in a modern world of alienation. As in Rodin, Malte depicts a self-reinforcing world whose structures of necessity and causality seem fundamentally distinct from those of the everyday world, a world created by the senses, and only knowable through them. In Rodin, however, the senses are servants of the real, whether that be the surface reality of the everyday object or the deeper reality of the expressive artwork; even when used to create, they create in response to something that is there. Thus, the dynamic of the gaze between the viewer and the artwork creates the conditions for the artwork's unique, transcendent nature as a response to its physically existing in the world. In Malte, on the other hand, the senses are involved in a neurotic feedback loop which circumvents that which banally 'exists', instead creating and reinforcing the beliefs of the perceiving subject. The senses show us what we want, or what we least want, to be there. Sensory experiences with Malte are often unsure of borders: the border between material reality and that which is supposed, but also the borders between the senses, or between the objects they perceive and even the borders between subjects. Within these conditions, the possibility of authenticity, for the artwork, and for the person, is called into question.

Wir entdecken wohl, daß wir die Rolle nicht wissen, wir suchen einen Spiegel, wir möchten abschminken und das Falsche abnehmen und wirklich sein. Aber irgendwo haftet uns noch ein Stück Verkleidung an, das wir vergessen. Eine Spur Übertreibung bleibt in unseren Augenbrauen, wir merken nicht, daß unsere Mundwinkel verbogen sind. Und so gehen wir herum, ein Gespött und eine Hälfte: weder Seiende, noch Schauspieler. (615)

Malte's 'wir' looks in the mirror in an attempt to relate to their embodied self as the 'Ding' is related to the 'Kunst-Ding'; we want to see ourselves as we are, abstracted from the realm we must inhabit. We long to be 'wirklich', but end up stuck, pitifully, between two forms of self-

\footnotetext{
${ }^{13}$ Rainer Maria Rilke, Die Aufzeichnungen des Malte Laurids Brigge in Kommentierte Ausgabe 4 vols. ed. Manfred Engel et al. (Franfurt am Main: Insel, 1996) III:435-665 (457). Citations by page number alone in this section refer to $K A$ vol. 3 .
} 
determination: the 'Schauspieler', the deliberate manipulator of appearances, and the 'Seiende', the authentic being. This longing plays out within the novel in the constant imagery of masks and masking, or of tearing away the face or exterior; these radical and often horrific aesthetic enactments of the drive to discover the real are then mirrored within the structures of the novel itself, such as, on the one hand, the excessive interest in depicting the macabre, or on the other the authorial claims of accuracy, allegedly serving to strip away appearances but used as a form of masking. The novel collapses the apparent opposition between masking and tearing away: both render the face unrecognisable. The imagery and textual manoeuvres expose aims at authenticity on the part of the subject and show them to be futile.

Unrecognisable faces are present throughout the novel. Our starting point is when Malte notes that people have not one face but many, replaceable faces:

Es giebt eine Menge Menschen, aber noch viel mehr Gesichter, denn jeder hat mehrere. Da sind Leute, die tragen ein Gesicht jahrelang, natürlich nutzt es sich ab, es wird schmutzig, es bricht in den Falten, es weitet sich aus wie Handschuhe, die man auf der Reise getragen hat. [...] Nun fragt es sich freilich, da sie mehrere Gesichter haben, was tun sie mit den andern? Sie heben sie auf. Ihre Kinder sollen sie tragen. Aber es kommt auch vor, daß ihre Hunde damit ausgehen. Weshalb auch nicht? Gesicht ist Gesicht. (457)

Where some eke them out, where others wear them out too soon, allowing the 'Nichtgesicht' to show through (457). The multiplicity of faces that each person has, and their readiness to wear out to the point of breaking or to give to another this body-part so deeply entangled with our understanding of identity - this picture of the face shakes the foundations of the self.

Faces within the novel are inconstant, the very antithesis of the facial integrity of Rodin, in which the faces of sculptures were able to express the 'Wesen' of the person represented. This unreliability drives the anxiety of (mis)recognition on which Malte's fears of identity are based. He is only able, for instance, to recreate the face of his dead mother in his memory after seeing the face of her distant cousin Mathilde Brahe. Only through seeing the features of his mother fragmented and rearranged on the face of another person can he reassemble the image of her that he carried around.

A mother who doesn't recognise her alleged son forms the example closest, perhaps, to Malte's heart. He retells the story of Grisha Otrepjev, read in a book he owned as a child. The false tsar summons his not-mother to Moscow to acknowledge him. However, to be falsely recognised might mean, Malte thinks, the breaking of the spell:

Aber die Erklärung der Mutter hatte, selbst als bewußter Betrug, noch die Macht, ihn zu verringern; sie hob ihn aus der Fülle seiner Erfindung; sie beschränkte ihn auf ein müdes Nachahmen; sie setzte ihn auf den Einzelnen herab, der er nicht war: sie machte ihn zum Betrüger. (587) 
By recognising him, she would allow his deceit to be tacitly acknowledged and he would become a mere imitator. This kind of recognition, formalised, rhetorical, is of particular interest for Malte, as it seems to bear little relationship to some absolute 'truth', rather to exist in a system of relations governed in part by imagination and self-conception. Even in his fear of being mistaken for a 'Fortgeworfener' we see the same set of worries: being mistaken for one of them is far more significant than fulfilling the criteria of identity, although, in the Bibliothèque National, he gives himself a once-over to check that he doesn't:

Zwar mein Kragen ist rein, meine Wäsche auch, und ich [...] könnte mit meiner Hand getrost in einen Kuchenteller greifen und etwas nehmen. Man würde nichts Auffälliges darin finden und mich nicht schelten und hinausweisen, denn es ist immerhin eine Hand aus den guten Kreisen, eine Hand, die vier- bis fünfmal täglich gewaschen wird. Ja, es ist nichts hinter den Nägeln, der Schreibfinger ist ohne Tinte, und besonders die Gelenke sind tadellos. (480)

This crisis of identity is largely based on language: his worries about the cleanliness of his hands, wrists, fingers centres around the kind of opprobrium they might bring upon themselves in polite circles. Marie Nagoi's non-recognition of Grisha Otrepjev is brought about by the utterance rather than the mental event which precedes it. When Charles the Bold's face is found half frozen off and eaten by dogs or wolves, it is split in two by a giant wound 'so daß von einem Gesicht keine Rede sein konnte' (592). Without a thing which can be called a face, other signs of identity have to be found; it is not enough that the fool recognises him, for recognition requires a process of naming.

Malte's dependence on language to process vision, and the subjectivity which this processing involves, is clear from the very beginning: in the first 'Aufzeichnung' he lists various things he has seen (and smelt), concluding, 'Das war nun mal so' (455). There is little more for him to do: to sense, and to record. In his recollection of childhood illness, Malte writes, 'Der Geschmack vom Apfelmus hielt lange vor, und das war schon alles mögliche, wenn man ihn irgendwie auslegte, unwillkürlich, und die reinliche Säure an Stelle von Gedanken in sich herumgehen ließ' (523). This substitution of sensory experience for thought describes the creative process of the Aufzeichnungen as a whole, or what purports to be its creative process, i.e. the descriptions Malte gives us of what he is doing, for instance his project 'ich lerne sehen' $(456,457)$. The relationship between sensing and creating is constantly undermined throughout the novel, in Malte's comments on his inability to transfer sense experiences into art, which is of course undercut by the fact that he has, to some extent, succeeded.

Habe ich schon gesagt, daß er blind war? Nein? Also er war blind. Er war blind und schrie. Ich fälsche, wenn ich das sage, ich unterschlage den Wagen, den er schob, ich tue, als hätte ich nicht bemerkt, daß er Blumenkohl ausrief. Aber ist das wesentlich? Und wenn es auch wesentlich wäre, kommt es nicht darauf an, was die ganze Sache für mich gewesen ist? Ich habe einen alten Mann gesehen, der blind war und schrie. Das habe ich gesehen. Gesehen. (485) 
Malte pre-empts the reproaches of the reader at his misrepresentation of the 'facts' of the matter. All that is important is how it was for him: the catchphrase, perhaps, of the psychological turn in aesthetic theory at the cusp of the twentieth century. ${ }^{14}$ Yet it is posed as a question: is that all there is to art? In Rodin, that which is there, in its deepest sense, and that which is important to the artist is one and the same. Rodin's art is a direct link between the viewer and the 'Wesen' of the represented object. Through the artist's hands the art object is created, bypassing thought; there is a necessity in the sculpture, driven by the underlying 'Leben' at work. And Rilke believed in this: that artistic creation was, and must be, so. Malte is unsure. Will the reader be content with his paratactic observations and experiences, and is their importance to him enough justification for the inclusion and exclusion of certain details? In this case, Malte gives first those details which for him are less important, and only later gets to the point, that the cauliflowerseller was blind. Leaving aside the emphatic juxtaposition of 'blind' and 'gesehen' (which, in his many questions, Malte implicitly dares the reader to see as exaggerated, a trick carried out more explicitly in the 'so übertrieben das auch klingt' of the mirror scene (529)), there is a necessary irony in this ordering, where he withholds that very detail which he claims to see as central, both suggesting that he himself has not yet come to believe that this is all that is 'wesentlich', and, more importantly, drawing our attention to the unknowability of the world of the artwork. Nothing exists outside of what he has seen relevant to tell us, and the reader is in no position to judge which of the details - cauliflower, blind - we should be given. Where with Rodin,we believe in the relevance of the artwork, in Malte we are denied this opportunity.

The passage which immediately follows the cauliflower-seller is the famous description of the house whose 'Innenseite' is grotesquely visible. Heidegger quotes this passage approvingly and at length in Grundprobleme der Phänomenologie, taking as read Malte's insistence that he is just describing what he sees. ${ }^{15}$ However, in this passage, the reader is once more set a challenge:

Wird man es glauben, daß es solche Häuser giebt? Nein, man wird sagen, ich fälsche. Diesmal ist es Wahrheit, nichts weggelassen, natürlich auch nichts hinzugetan. Woher sollte ich es nehmen? Man weiß, daß ich arm bin. Man weiß es. (485)

\footnotetext{
14 'Die moderne Ästhetik, die den entscheidenden Schritt vom ästhetischen Objektivismus zum ästhetischen Subjektivismus gemacht hat, d.h. die bei ihren Untersuchungen nicht mehr von der Form des ästhetischen Objektes, sondern vom Verhalten des betrachtenden Subjekts ausgeht, gipfelt in einer Theorie, die man mit einem allgemeinen und weiten Namen als Einfühlungslehre bezeichnen kann.' Wilhelm Worringer, Abstraktion und Einfühlung (1907; Munich: Piper, 1921) p. 2. The main emphasis of this subjective turn was the viewer, rather than the artist, but in some cases the difference between a creator and a viewer was downplayed, for instance in the architectural theory of August Schmarsow (e.g. Das Wesen der architektonischen Schöpfung 1893), or in Adolf Hildebrand's Das Problem der Form in der bildenden Kunst (1893; Strassburg: Heitz \& Mündl, 1901). It could also be said to be the catchphrase of the 'impressionistic' turn in art criticism of the same point, in, for example, the early Meier-Graefe.

${ }^{15}$ Heidegger, Gesamtausgabe: Band 24 - Die Grundprobleme der Phänomenologie ed. Friedrich-Wilhelm von Hermann (Frankfurt am Main: Klostermann, 1975) p. 246.
} 
This is precisely the challenge that Rodin's art, at least according to Rilke, sets the viewer, a challenge which it took thirteen years for audiences to rise to: to believe that the work of art had a privileged relationship with reality, and to trust that the artist was responding to what was 'really' there. Here, however, the possibility of this is called into question with the ironic suggestion that imagination is the property of the rich.

Within the description of the house, Malte calls on all the senses to fully evoke the 'Leben', however horrifying, which he claims to see there. Within Malte the use of sensory description often transcends the boundaries between the senses; in some cases, it is made clear that even within the logic of the novel, something is amiss:

'Nein, Kind, das bildest du dir ein', sagte der Graf gutmütig, aber er hatte auf einmal dasselbe beunruhigte Gesicht, das er vorstreckte über den beiden Damen. Die Gräfin war von ihrer sogenannten Einbildung nicht abzubringen. Sie sah ganz angestrengt aus, wie jemand, der nicht gestört sein will. Sie machte kleine, abwinkende Bewegungen mit ihren weichen Ringhänden, jemand sagte 'sst', und es wurde plötzlich ganz still.[...]

'Mama riecht', sagte Wjera Schulin[...], 'da müssen wir immer alle still sein, sie riecht mit den Ohren'. (555)

Far from the sensory integration that Rilke sees in Rodin's work, these perceptual mis-wirings are symptoms of the breakdown of the subject that characterises the novel. Thus, even in instances where cross-sensory description can be attributed more to the lyricism of the novel, the overtones are sinister, such as the 'grauriechende[ ] Kälte' into which schoolchildren must wake (603) or more explicitly, in the 'mirror' scene, where the mask he puts on 'roch eigentümlich hohl' (528).

On his visit to the Salpêtrière hospital (492-8), Malte experiences a combination of sensory deprivation and sensory fusion. His nervous exploration of the space, in which he paces up and down, takes place in the semi-darkness. His description of the air, 'schlecht, schwer, voll Kleider und Atem' seems to suggest smell, yet the overwhelming impression is one of physical oppression ('schwer' and 'voll'); when Malte notices ether, where we would expect, again, reference to smell, its 'starke, steigernde Kühle' is described. Synaesthetic perception is predicated on the separability of the object's properties and the subject's experience of them, and by leading to sense experiences which would commonly seem nonsensical, the truthfulness of all perception is called into question. In simultaneously isolating and combining smell, touch and sight, this scene warns against placing too much trust in the senses at all - or in the arbitrary divisions imposed between them.

One of the most striking images from the hospital is of bandages which isolate body parts from persons: 
Verbände, die den ganzen Kopf Schichte um Schichte umzogen, bis nur noch ein einziges Auge da war, das niemandem mehr gehörte. [...] Verbände, die man geöffnet hatte und in denen nun, wie in einem schmutzigen Bett, eine Hand lag, die keine mehr war; und ein eingebundenes Bein, das aus der Reihe herausstand, groß wie ein ganzer Mensch. (493)

By focussing intently on individual body parts Malte both indicates and contributes to his larger fears of fragmentation. This plays out, as Andreas Huyssen notes, on the surface: 'In every case, the imaginary unity of the body surface is disrupted ${ }^{16}{ }^{16}$ Just as the decoupling and re-attachment of objects and sense-perception through synaesthesia draws attention to a general perceptual scepticism, the very fact that this isolation is possible undermines the idea of a stable body. This disruption of a surface unity is also suggested by the porous sensory boundaries between subjects. At the very beginning of the novel, Malte describes a woman he has seen who seems to have little trust in her sense of sight:

Ich habe eine schwangere Frau gesehen. Sie schob sich schwer an einer hohen, warmen Mauer entlang, nach der sie manchmal tastete, wie um sich zu überzeugen, ob sie noch da sei. Ja, sie war noch da. (455)

Although he has only watched her from a distance, her actions are reported with a degree of psychological and physiological identification: the wall is 'warm', her movements 'schwer', and in the final sentence, 'Ja, sie war noch da,' he ventriloquises the woman. For Malte, sight does not involve a mutual 'letting be' of viewer and viewed: watching entails participation. This is why, in the preceding sentences, it is only when the line of sight is interrupted that Malte is relieved of the ethical burden of watching someone die (or at least collapse): 'Ich habe einen Menschen gesehen, welcher schwankte und umsank. Die Leute versammelten sich um ihn, das ersparte mir den Rest' (455). The passage in which Malte follows and compulsively mimics a man who hops and turns his collar uncontrollably takes this participation to another level: in watching, he feels compelled to physically identify with the man. ${ }^{17}$ Sight becomes inseparable from touch and movement, and boundaries between subjects are dissolved through this sensory elision.

\footnotetext{
${ }^{16}$ Andreas Huyssen, 'Paris / Childhood: The Fragmented Body in Rilke's Notebooks of Malte Laurids Brigge' in Modernity and the Text: Revisions of German Modernism (New York: Columbia University Press, 1989) 113-42 (p. 118).

${ }^{17}$ Friedrich Kittler makes the point that while this may seem, as has been suggested, a 'clinically exact' portrait of a particular feature of epilepsy, moreover in line with the kinds of research being done into the condition at the time, it is not Rilke who is portraying the man, but Malte, who is mimicking him. Friedrich Kittler, Aufschreibesysteme $1800.19003^{\text {rd }}$ edition (Munich: Fink, 1995) p. 416.
} 
In the Aufzeichnungen, for the most part, looking is looking at, and gazes are rarely met; yet even this one-directional form of looking endangers the boundaries between the viewer and the viewed, as with the man with the 'Spring-Tic'. Thus, the distinction which Simmel makes between a reciprocal and non-reciprocal look, in which the former brings about a unique and self-disclosing union, is broken down; the union is made not through eyes, but through bodies. We might revisit this taxonomy of looking and break it down on slightly different lines: between persons, and between a person and an object, and in only the first of these two cases can the reciprocal look be sustained. An exploration of gazes met and unmet in the novel shows that here they undermine this division, yet ultimately restate it: the instances in which gazes are returned by objects, and people are shown to be incapable of returning the gaze, are uncanny and gruesome in their deviation.

When Malte appears, masked, costumed, and terrified, running from his mirror image, the servants, with whom he seeks refuge, laugh at him, not knowing his fear:

Sieversen erzählte bis an ihr Ende, wie ich umgesunken wäre und wie sie immer noch weitergelacht hätten in der Meinung, das gehöre dazu. Sie waren es so gewöhnt bei mir. Aber dann wäre ich doch immerzu liegengeblieben und hätte nicht geantwortet. Und der Schrecken, als sie endlich entdeckten, daß ich ohne Besinnung sei und da lag wie ein Stück in allen den Tüchern, rein wie ein Stück. (530)

The mask obscures their access to Malte's eyes and they are unable to read his emotions; more importantly, however, they are unable to see that what they are dealing with is no longer a conscious person but a 'Stück', barely more than just another piece of fabric in the pile. It is this that scares them: to have looked at someone in the assumption that they could have had their look returned, and to find that this was not the case.

Characters in Malte are often prevented, physically and psychologically, from participating in the reciprocal look. They are blind, like the newspaper seller (600) or their eyes are full of mucus or tears (the 'Fortgeworfene' (481); Mathilde Brahe in (472) or the woman in the crêpe hat at the hospital, (493)), or, like Erik's or those of the paralysed man at the hospital, do not work in tandem. Sten, Count Brahe's valet, never meets one's gaze, instead resting his eyes behind those he looks at, and it is assumed this is because he is in contact with ghosts. Also terrifying are the lengths that people will go to to bring about a meeting of the gaze when it is no longer possible, as seen on a Neapolitan tram:

Das blasse, dicke Mädchen hätte so, angelehnt an ihre Nachbarin, ruhig sterben können. Aber ihre Mutter gab das nicht zu. Sie bereitete ihr alle möglichen Schwierigkeiten. [...] Sie verrieb auf ihrer Stirn eine Flüssigkeit, die jemand gebracht hatte, und wenn die Augen dann ein wenig verrollten, so begann sie an ihr zu rütteln, damit der Blick wieder nach vorne käme. Sie schrie in diese Augen hinein, die nicht hörten, sie zerrte und zog das Ganze wie eine Puppe hin und her, und schließlich holte sie aus und schlug mit aller Kraft in das dicke Gesicht, damit es nicht stürbe. Damals fürchtete ich mich. (569) 
The 'unvergleichliche Beziehung' as Simmel calls it brought about by the met gaze is cut; the alienation of Malte's world, the disconnection between people, their mutual unknowability, is exemplified in their inability to look one another in the eye. ${ }^{18}$ As here, fear is often the product of these disrupted sensory experiences: when child Malte faints, unbeknown to the servants, or when Malte feels a connection to the dead man sitting at his place at the crémerie, whose eyes he cannot see (489). Returning to the Schulins, where Countess Schulin is smelling with her ears, the same fear arises:

Aber auf einmal (war es die Hitze in den Zimmern oder das viele nahe Licht) überfiel mich zum erstenmal in meinem Leben etwas wie Gespensterfurcht. Es wurde mir klar, daß alle die deutlichen großen Menschen, die eben noch gesprochen und gelacht hatten, gebückt herumgingen und sich mit etwas Unsichtbarem beschäftigten; daß sie zugaben, daß da etwas war, was sie nicht sahen. Und es war schrecklich, daß es stärker war als sie alle. (555)

In this passage the fear that the child Malte feels reaches outside of the novel, speaking to a universal fear of one's childhood: the coming to knowledge of the adult world, which is not ordered, and in which adults do not always respond to reason. And at the same time, it is the fear brought about by modernity, in which the new is only available as a negative injunction. Creation, in this world, is next to impossible.

\section{Malte as mimicry}

At a party in Venice, Malte finds himself being watched by a young woman. She is not looking with her eyes, but, as one might already expect in a novel so sensorially confused, with her mouth, and her looking takes on the form of mimicking his facial expressions:

Sie stand allein vor einem strahlenden Fenster und betrachtete mich; nicht eigentlich mit den Augen, die ernst und nachdenklich waren, sondern geradezu mit dem Mund, der dem offenbar bösen Ausdruck meines Gesichtes ironisch nachahmte. Ich fühlte sofort die ungeduldige Spannung in meinen Zügen und nahm ein gelassenes Gesicht an, worauf ihr Mund natürlich wurde und hochmütig. Dann, nach kurzem Bedenken, lächelten wir einander gleichzeitig zu. (625)

Despite the dislocation of sensory processes, this episode stands out as one of the few moments in the novel where there is mutual recognition between characters; the initial mimicking is antagonistic, but the final simultaneous smiles suggest a non-pathological sensory connection, mimesis as reciprocal acknowledgement. This is not the 'müdes Nachahmen' of a Grisha Otrepjev, but a fertile, cooperative process: it suggests a possible route forward out of creative sterility and self-doubt; and indeed shortly after this passage, the young woman sings, her song breaking through temporality itself: 'Niemand hatte es erwartet. [...] Und zum Schluß war eine solche Sicherheit in ihr, als ob sie seit Jahren gewußt hätte, daß sie in diesem Augenblick würde einzusetzen haben.'

\footnotetext{
${ }^{18}$ Simmel, p. 280.
} 
How can this image help us align Rodin and Malte? The texts, I suggest, stand in relation to one another as do Malte and the young woman. Malte's 'Aufzeichnungen', in their exaggerated sensory integration and fragmentation, in their relentless examination of the frustrated gaze, mimic back at Rodin its overwhelmingly positive conclusions about the artwork. Malte responds not with its eyes, but the gestures of its entire textual face: the fragmented form, the uneasily autobiographical, confessional style, the lacunae of narrative logic or chronology as well as the content of the 'sketches' together warp and distend the ideas of Rodin in an aggressive aesthetic interrogation.

Mimesis is thematised in both texts. In Rodin, as we have seen, the representational possibilities of the part and the whole underpinned the separation out of 'Ding' and 'Kunst-Ding'. In Malte, it operates as part of the disintegration of boundaries between subjects, and in Malte's 'playing' himself. Mimesis is also a function of the texts as texts: in his ekphrases of Rodin's sculptures, Rilke is beginning to search for the poetic language he will later find in Neue Gedichte to make his own art after Rodin's model. Thus the text aims towards a certain rounded autonomy, made up as if of 'Fläche' and 'Stellen' and, in its rhythms, displaying the sort of movement Rilke noticed in Rodin's work, intuitable but not comprehensible through the constraints of space and time, instead aiming at 'Ewigkeit'. In Malte, the text imitates the parataxis of the modern city, using 'literary effects', as Michael Minden writes in comparing Malte with Ingeborg Bachmann's Malina, 'that do not simply decry [...] depersonalisation (although they do that too), but mimic it.' Here, what is important is the use to which this is put: 'This use of mimesis, moreover, is not just an aesthetic measure, but a form of struggle or resistance, since mimesis is also a survival mechanism. ${ }^{19}$

Malte is a text in conversation with a variety of genres, and in each case these are not written, but re-written: the young Malte himself transcribing Baudelaire, the intrusion of Rilke's letters to Westhoff and Salomé into the text, such as the description of the bouquinistes, and the episodes of narrative that seem to function rather, as Minden points out, as 'reflections upon narrative' ${ }^{20}$ We might see Malte then as a form of pathologically multi-sensory 'close reading', which, as D.A. Miller suggests 'has always been radically cloven: here, on one side, my ambition to master a text, to write over its language and refashion it to the cut of my argument, to which it is utterly indifferent; there, on the other, my longing to write in this language, to identify and combine with it. ${ }^{21}$ Malte, more than anyone, succumbs to this second, to what close reading, according to

\footnotetext{
${ }^{19}$ Michael Minden, 'Modernism's Struggle for the Soul: Rainer Maria Rilke's Die Aufzeichnungen des Malte Laurids Brigge and Ingeborg Bachmann's Malina' German Life and Letters 67 (2014) 320-40 (p. 323).

${ }^{20}$ Minden, p. 323.

${ }^{21}$ D. A. Miller, Jane Austen, or, the Secret of Style (Princeton: Princeton University Press, 2005) p. 58.
} 
Miller, really is: 'an almost infantile desire to be close, period, as close as one can get, without literal plagiarism, to merging with the mother-text' (58) (for Malte, and in some sense Rilke, the plagiarism is no issue). And in doing so, the novel throws the accusation of the former back to Rodin, where the works are written over, refashioned. ${ }^{22}$ (This can be seen in particular in the lecture, where we might note, following Brigid Doherty's extensive discussion of the implications of its delivery, a bolstering of the writer's self at the expense of the artist's: it had been pre-written; the works were not described in any explicit terms, nor were images shown on slides as had recently become possible; Rilke refused to name Rodin at the start of his lecture to avoid giving an 'illusion of unity' between speaker and audience. $)^{23}$

To read Malte as a reverse mirror image of Rodin is an example of the reading process Rilke himself advised, of 'gegen den Strich lesen' ${ }^{24}$ It is here that we can resolve the aesthetic problem of the novel. Malte, in noticing the young woman and loosening his facial expression, recognises and opens himself up to another, acknowledges the epistemological limits of the modern subject, and, a fortiori, the modern writer. It is this that Rilke's earlier aesthetic theory must embrace to move forward, and only at this point can the two works smile at one another, find common aesthetic ground.

10142 words

\footnotetext{
${ }^{22}$ Jaś Elsner has claimed that this is true of all art historical description; I will follow this claim with regard to Rilke alongside the other writers of the books in the series to which Auguste Rodin was a contribution (Richard Muther's Die Kunst. Sammlung illustrierter Monographien) in a further article. Jaś Elsner, 'Art History as Ekphrasis' Art History 33 (2010) 11-27.

${ }^{23}$ Doherty, p. 327.

${ }^{24}$ Briefe aus den Jahren 1914 bis 1921 ed. Ruth Sieber-Rilke and Carl Sieber (Leipzig: Insel 1937) p. 241.
} 